\title{
AEROBIC DISSIMILATION OF GLUCOSE BY HETEROLACTIC BACTERIA
}

\author{
III. ALDEHYDE DEHYDROGENASE AND ALCOHOL \\ DEHYDROGENASE OF LEUCONOSTOC MESENTEROIDES
}

\author{
TOMOYUKI KAZAHAYA ${ }^{1}$, KEIICHI KAWAI, SHIGETAKA YASHIMA \\ AND YUJI SASAKI \\ Department of Microbial Technology, Faculty of Agriculture, \\ Hokkaido University, Sapporo, Hokkaido 060
}

(Received October 16, 1971)

\begin{abstract}
Properties of CoA-dependent aldehyde dehydrogenase and NAD-linked alcohol dehydrogenase of Leuconostoc mesenteroides IFO 3426 were studied, and it was found that the two dehydrogenases cannot be separated from each other, as well as from those of Escherichia coli B, by various methods of enzyme fractionation. It was also observed that the dehydrogenases of Leuconostoc mesenteroides appeared in a precipitate fraction prepared by centrifugation at $105,000 \times g$, and estimated to be associated with intracellular particles containing RNA.
\end{abstract}

The metabolic pathway of ethanol production from acetyl phosphate in heterolactic fermentation has been believed to be; acetyl phosphate $\rightarrow$ acetyl$\mathrm{CoA} \rightarrow$ acetaldehyde $\rightarrow$ ethanol ( 1$)$. Although the properties of phosphate acetyltransferase [EC 2.3.1.8] (1-4) or alcohol dehydrogenase (ADH) [EC 1.1.1.1; 1.1.1.2] $(2,5-7)$ isolated from heterolactic bacteria have been reported, the existence of acetaldehyde dehydrogenase (ALDH) [EC 1.2.1.10] has not yet been recognized.

To clarify the mechanism of aerobic glucose dissimilation by heterolactic bacteria, on which some unexpected phenomena were reported, studies on basic characteristics of ALDH may be considered to be essential ( 8 ). During the course of studies on the purification of ALDH of Leuconostoc mesenteroides IFO 3426, we found that ALDH and ADH may be considered as enzymes associated with the same subcellular organelle.

The present paper concerns the partial purification and properties of these

1 Present address: Developmental Laboratories, Kawasaki Plant, Meiji Seika Kaisha, Ltd., 580 Horikawa-cho, Kawasaki-shi, Kanagawa-ken 244. 
dehydrogenases in the organism which was recognized to be a typical heterolactic coccus.

\section{MATERIALS AND METHODS}

Organism. Leu. mesenteroides IFO 3426 was used throughout this study and procedures for cultivation and preparation of washed cells were the same as previously reported (9).

Methods. Determination of activities of ALDH was carried out as follows: After incubation $\left(30^{\circ}, 5 \mathrm{~min}\right)$ of a mixture containing $200 \mu$ moles of dipotassium phosphate ( $\mathrm{pH} 8.0$ ), $5 \mu$ moles of reduced glutathione, $0.5 \mu$ mole of $\mathrm{NAD}, 12.5 \mathrm{~m} \mu$ moles of $\mathrm{CoA}$, enzyme (0.003 to 0.006 unit) and deionized water to bring a total volume of $975 \mu 1$, the reaction was started by the addition of $25 \mu 1$ of $1 \mathrm{M}$ acetaldehyde. The initial rate of formation of $\mathrm{NADH}_{2}$ was calculated from the increase of optical density at $340 \mathrm{~m} \mu$. For the estimation of $\mathrm{ADH}$ activities, $975 \mu 1$ of a reaction mixture containing $30 \mu$ moles of potassium phosphate buffer $(\mathrm{pH} 7.0), 0.1 \mu$ mole of $\mathrm{NADH}_{2}$ and the enzyme ( 0.01 to 0.02 unit) was held at $30^{\circ}$ for $5 \mathrm{~min}$, followed by the addition of 25 $\mu 1$ of $50 \mathrm{~mm}$ acetaldehyde to start the reaction. From the initial rate of decrease in optical density at $340 \mathrm{~m} \mu$, the activity of $\mathrm{ADH}$ was estimated. $\mathrm{NADH}_{2}$ oxidase, $\mathrm{NADPH}_{2}$ oxidase, $\mathrm{NADH}_{2}$ peroxidase or $\mathrm{NADPH}_{2}$ peroxidase activity was assayed by the method reported previously (9). Activities of lactate dehydrogenase and acetate kinase were determined according to the methods of DENNIS and KAPLAN (10) and Rose et al. (11), respectively. The activity of phosphate acetyltransferase was estimated as previously reported (3). All determinations of enzymic activities were made in quartz cuvettes with 1-cm light path, using Hitachi Model 124 spectrophotometer equipped with an automatic recorder, except in the case of phosphate acetyltransferase and acetate kinase. One unit of enzyme activity was defined as the amount of enzyme causing change in one $\mu$ mole of substrate per min, and specific activity was defined as units per mg of protein.

Concentration of protein or acetaldehyde was estimated by the method of LOWRY et al. (12) or BARKER and SUMMERSON (13), respectively. When samples contained high concentrations of cysteine, they were dialyzed overnight before the determinations of protein. Ultracentrifugation of the enzyme solution was carried out in a Hitachi-65P ultracentrifuge at $5^{\circ}$.

Materials. Acetyl-CoA and acetyl phosphate were purchased from Boeringer and Soehne GmbH. NADP, NADPH $\mathrm{N}_{2}$ and RNase $\mathrm{T}_{1}$ were obtained from Sigma Chemical Co., Ltd. NAD, $\mathrm{NADH}_{2}$, GMP, GDP, ATP, ADP, AMP and guanosine were purchased from Kyowa Hakko Co., Ltd. CoA and Chromagel A-2 were obtained from Takeda Chem. Ind. Co., Ltd., and Wako Pure Chemical Co., Ltd, respectively. Other reagents were of analytical grade. 


\section{RESULTS}

In preliminary experiments, it was found that activities of both ALDH and $\mathrm{ADH}$ were always detected in the same fractions obtained by fractionation with ammonium sulfate, streptomycin, protamine, acetone, ethanol, calcium phosphate gel, DEAE-cellulose column chromatography, Sephadex G-200 column chromatography, and ultracentrifugation. These results suggesting that two dehydrogenases may constitute a multienzyme complex or a complex associated with subcellular organelle led us to prepare the enzyme fraction including both the enzymes, but not unfavorable enzymes, i.e., $\mathrm{NAD}(\mathrm{P}) \mathrm{H}_{2}$ oxidase or phosphate transacetylase which may interfere in the measurement of activities of ALDH and $\mathrm{ADH}$.

\section{Purification of $A L D H$ and $A D H$}

All operations of enzyme purification were performed at $5^{\circ}$ and centrifugation was carried out at $15,000 \times g$ for $20 \mathrm{~min}$, unless otherwise stated.

Washed cells obtained from a 5-litre culture were suspended in $25 \mathrm{ml}$ of $5 \times 10^{-2} \mathrm{M}$ potassium phosphate buffer ( $\mathrm{pH} 7.0$ ) containing $0.1 \mathrm{M}$ cysteine, exposed to sonic oscillation $(20 \mathrm{kc}$ ) for $60 \mathrm{~min}$, and the supernatant (cell-free extract; $32 \mathrm{ml}$ ) was prepared by centrifugation. The supernatant solution thus obtained was diluted with the same buffer to give a protein concentration of $25 \mathrm{mg} / \mathrm{ml}$, and added with $250 \mathrm{mg}$ of streptomycin. After stirring for $5 \mathrm{~min}$, precipitate formed was removed by centrifugation. To the supernatant solution ( $48 \mathrm{ml}$ ) thus obtained was gently added $37 \mathrm{ml}$ of saturated ammonium

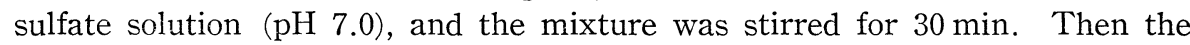
mixture was centrifuged to remove the precipitate, and to the supernatant was added $31 \mathrm{ml}$ of the same ammonium sulfate solution. After $30 \mathrm{~min}$ of stirring, the precipitate was collected by centrifugation and dissolved in $10 \mathrm{ml}$ of $5 \times 10^{-2} \mathrm{M}$ potassium phosphate buffer containing $25 \mathrm{mM}$ cysteine ( $\mathrm{pH} 7.0$ ). The solution thus prepared was found to contain the activities of ALDH, ADH, $\mathrm{NADH}_{2}$ oxidase and phosphate acetyltransferase. To remove the oxidase and transferase, $9 \mathrm{ml}$ of the enzyme solution was applied on a column $(2.7 \times 85 \mathrm{~cm})$ of Sephadex G-200 and fractionated with the same buffer at a flow rate of 15 $\mathrm{ml} / \mathrm{hr}$. As shown in Fig. 1, the activities of ALDH and ADH appeared in void volume fractions with complete separation from $\mathrm{NADH}_{2}$ oxidase and phosphate acetyltransferase. The fractions Nos. $13-17$ ( $10 \mathrm{ml}$ per fraction) were pooled and insoluble substances were collected by centrifugation at $105,000 \times g$ for $2 \mathrm{hr}$. The insoluble fraction was resuspended in the potassium phosphate buffer and washed twice by centrifugation under the same condition as described above. The washed insoluble material was suspended in the same buffer and this suspension was used as a partially purified preparation of ALDH and ADH. Activities of $\mathrm{NADH}_{2}$ oxidase, $\mathrm{NADPH}_{2}$ oxidase, lactate dehydrogenase, $\mathrm{NADH}_{2}$ peroxidase, $\mathrm{NADPH}_{2}$ peroxidase, phosphate acetyltransferase, and acetate kinase were not detectable in this purified preparation. Whole procedure of the purification is summarized in Table 1. 


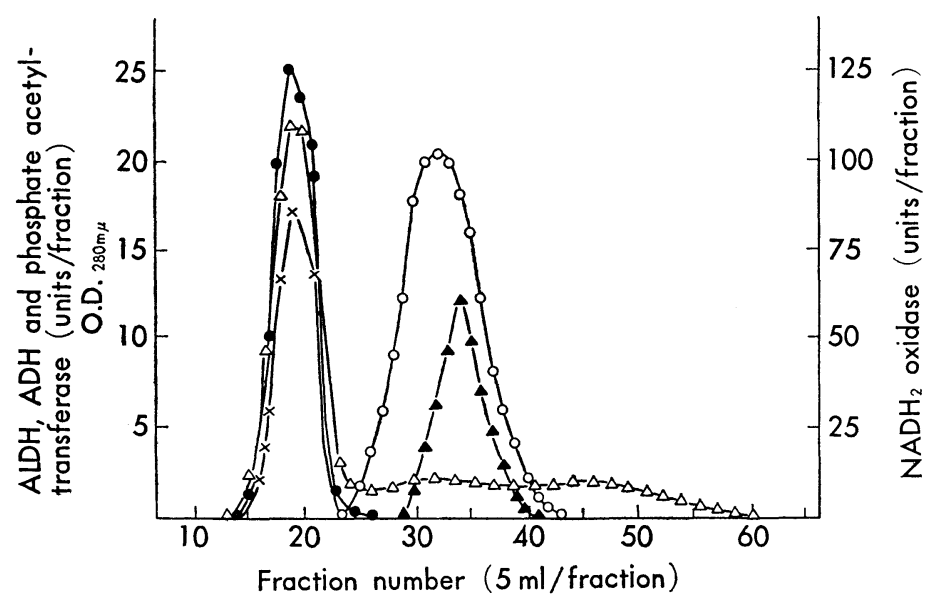

Fig. 1. Separation of ALDH and ADH from both $\mathrm{NADH}_{2}$ oxidase and phosphate acetyltransferase by Sephadex G-200 column chromatography.

- - ALDH, - $\times-\mathrm{ADH},-\mathrm{O}-\mathrm{NADH}_{2}$ oxidase, - $\mathbf{-}-$ phosphate acetyltransferase, $-\triangle-\mathrm{OD}_{280 \mathrm{~m} \mu}$.

Table 1. Purification of ALDH and ADH.

\begin{tabular}{l|c|c|c|c}
\hline \multirow{2}{*}{ Fraction } & \multicolumn{2}{|c|}{$\begin{array}{c}\text { Specific activity } \\
\text { (unit/mg protein) }\end{array}$} & $\begin{array}{c}\text { Purification } \\
\text { of ALDH } \\
\text { (fold) }\end{array}$ & $\begin{array}{c}\text { Yield of } \\
\text { ALDH } \\
\text { (\%) }\end{array}$ \\
\cline { 2 - 5 } & ALDH & ADH & 1.0 & 100 \\
\hline Cell-free extract & 0.12 & - & 1.1 & 85 \\
Streptomycin supernatant & 0.14 & - & 2.1 & 79 \\
$\begin{array}{l}\text { Ammonium sulfate } \\
\text { (45-60\% saturation) }\end{array}$ & 0.27 & - & 2.4 & 24 \\
Sephadex G-200 eluate & 0.31 & 0.22 & 6.6 & 23 \\
$105,000 \times g$ precipitate & 0.87 & 0.32 & & \\
\hline
\end{tabular}

\section{Properties of $A L D H$}

Requirement for enzyme reaction and substrate specificity. Fig. 2 shows the requirement of $\mathrm{CoA}, \mathrm{NAD}$ and acetaldehyde for the forward reaction of ALDH, and it was found that NADP was unable to replace NAD under the standard assay conditions. It was also observed that activity of the enzyme decreased to $14 \%$ when reduced glutathione was omitted from the reaction mixture. As shown in Table 2, propionaldehyde, butyraldehyde or isobutyraldehyde was found to serve as a substrate as acetaldehyde did, indicating the broad substrate specificity of the enzyme.

Reversibility. When acetyl-CoA and $\mathrm{NADH}_{2}$ were used as substrates, de- 


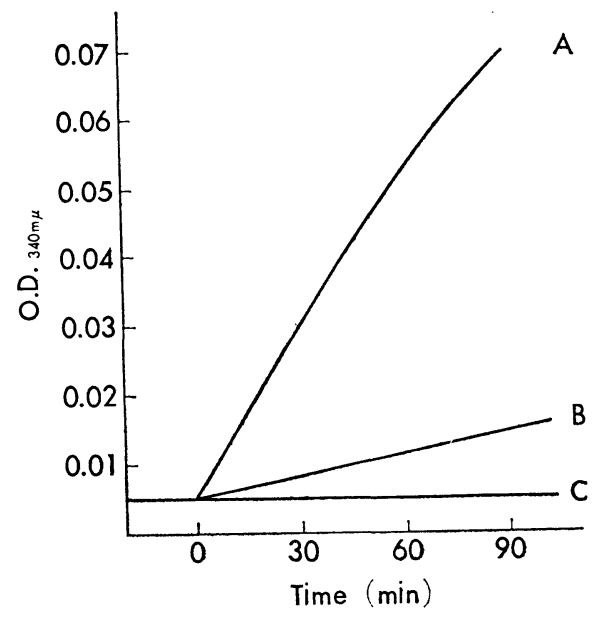

Fig. 2. Requirements for ALDH reaction.

Complete reaction mixture contained $200 \mu$ moles of potassium phosphate ( $\mathrm{pH} 8.0$ ), $0.5 \mu$ mole of NAD, $12.5 \mathrm{~m} \mu$ moles of CoA, 25 $\mu$ moles of acetaldehyde and enzyme in a final volume of $1 \mathrm{ml}$.

A : Complete. B: Complete minus reduced glutathione.

$\mathrm{C}$ : Complete minus enzyme, NAD, CoA or acetaldehyde.

Table 2. Substrate specificity of ALDH.

\begin{tabular}{l|c}
\hline \multicolumn{1}{c|}{ Substrate } & Relative activity (\%) \\
\hline Formaldehyde & 7 \\
Acetaldehyde & 100 \\
Propionaldehyde & 115 \\
Butyraldehyde & 31 \\
Isobutyraldehyde & 14 \\
Benzaldehyde & 0 \\
\hline
\end{tabular}

crease of optical density at $232 \mathrm{~m} \mu$ corresponding to the concentration of acetyl-CoA was detected as shown in Fig. 3, and it was suggested that thiol ester of acetyl-CoA may be cleaved by the action of ALDH in the presence of $\mathrm{NADH}_{2}$. Moreover, it was recognized that optical density at $340 \mathrm{~m} \mu$ also decreased during the reaction, and an equimolar relationship between decreases of acetyl-CoA and $\mathrm{NADH}_{2}$ was calculated. From these results, ALDH of Leu. mesenteroides can also catalyze the backward reaction of the following equation:

$$
\text { aldehyde(s) }+\mathrm{CoA}+\mathrm{NAD} \rightleftharpoons \mathrm{acyl}-\mathrm{CoA}+\mathrm{NADH}_{2}
$$




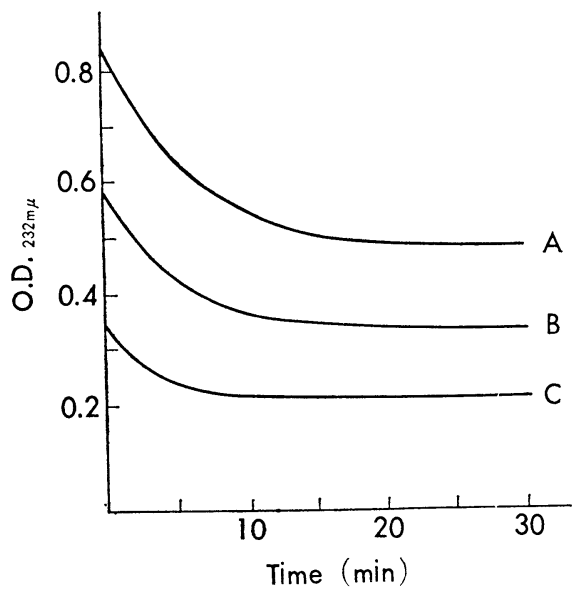

Fig. 3. Decrease of acetyl-CoA by ALDH in the presence of $\mathrm{NADH}_{2}$.

Basal reaction mixture contained $200 \mu$ moles of potassium phosphate buffer ( $\mathrm{pH} \mathrm{8.0)}$ and $63.4 \mathrm{~m} \mu$ moles of $\mathrm{NADH}_{2}$ in a final volume of $1 \mathrm{ml}$. To $\mathrm{A}, \mathrm{B}$ or $\mathrm{C}$ was added 93,62 or $31 \mathrm{~m} \mu$ moles of acetyl-CoA, respectively. The same reaction mixture without acetyl-CoA was used as a blank. The reaction was started by the addition of the enzyme solution. It was calculated that 88,92 or $100 \%$ of acetyl-CoA was decreased in the case of $\mathrm{A}, \mathrm{B}$ or $\mathrm{C}$, respectively.

Effect of buffer and temperature. As shown in Fig. 4, a remarkable effect of concentration of buffer on the reaction was found and the reaction seemed to require a high ionic concentration. The reaction was completely inhibited when $0.2 \mathrm{M}$ boric acid- $\mathrm{Na}_{2} \mathrm{CO}_{3}$ buffer ( $\mathrm{pH}$ 8.0), glycine- $\mathrm{NaOH}$ buffer ( $\mathrm{pH} 8.0$ ) or $\mathrm{NH}_{4} \mathrm{Cl}-\mathrm{NH}_{4} \mathrm{OH}$ buffer ( $\mathrm{pH} 8.0$ ) was used.

It was also found that optimum $\mathrm{pH}$ and temperature for the reaction are 8 and $30^{\circ}$, respectively. As shown in Fig. 5, ALDH was inactivated by a heat treatment at $45^{\circ}$ for $15 \mathrm{~min}$.

$\mathrm{Km}$ values. $\mathrm{Km}$ values for $\mathrm{CoA}, \mathrm{NAD}$ and acetaldehyde were estimated as $9 \times 10^{-6} \mathrm{M}, 1.7 \times 10^{-4} \mathrm{M}$, and $3.7 \times 10^{-3} \mathrm{M}$, respectively, from the Lineweaver and Burk's plots.

Effect of various compounds. In the presence of $10^{-3}$ or $10^{-4} \mathrm{M} \mathrm{Na}_{2} \mathrm{HAsO}_{4}$, or $10^{-3} \mathrm{M}$ of $\mathrm{AgNO}_{3}, \mathrm{HgCl}_{2}$ or $\mathrm{CuSO}_{4}, 100,32,20,31$ or $49 \%$ inhibition was observed, respectively, whereas, cations $\left(\mathrm{K}^{+}, \mathrm{Na}^{+}, \mathrm{Li}^{+}, \mathrm{Mg}^{2+}, \mathrm{Mn}^{2+}, \mathrm{Zn}^{2+}\right.$, $\mathrm{Ca}^{2+}, \mathrm{Fe}^{2+}$ and $\mathrm{Fe}^{3+}$ ), EDTA, p-chloromercuribenzoate, iodoacetate, sodium azide and dipyridyl showed no inhibition at a concentration of $10^{-3} \mathrm{M}$. At the same concentration, lactic acid, acetic acid, ethanol, acetyl phosphate and pyruvic acid did not show any inhibitory effect on the reaction, as did $10^{-4} \mathrm{M}$ of NADP or $\mathrm{NADPH}_{2}$. Although $10^{-3} \mathrm{M}$ of adenine, adenosine, guanine, guanosine, GMP or GDP did not affect the reaction, the same concentration of AMP, 


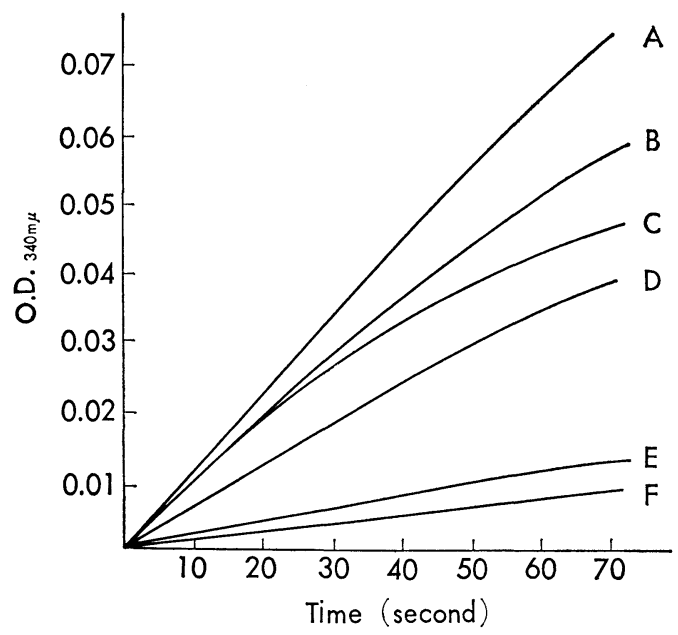

Fig. 4. Effect of phosphate or Tris- $\mathrm{HCl}$ buffer on $\mathrm{ALDH}$ reaction at different concentrations or pHs.

A : $0.2 \mathrm{M}$ potassium phosphate $(\mathrm{pH} 8.0)$. B: $0.2 \mathrm{M}$ potassium phosphate $(\mathrm{pH} 7.0)$. C : $0.2 \mathrm{M}$ Tris- $\mathrm{HCl}(\mathrm{pH} 8.0)$. D : $0.04 \mathrm{M}$ potassium phosphate $(\mathrm{pH} 8.0)$. E: $0.04 \mathrm{M}$ potassium phosphate $(\mathrm{pH} 7.0)$. F : $0.04 \mathrm{M}$ Tris- $\mathrm{HCl}(\mathrm{pH} 8.0)$.

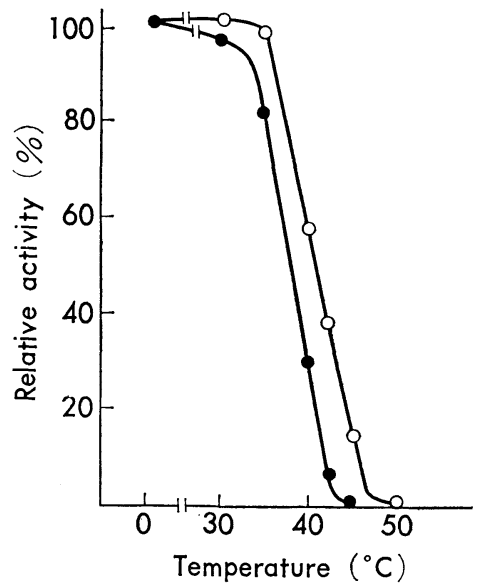

Fig. 5. Thermostability of ALDH or ADH.

Purified enzyme preparation was treated for $15 \mathrm{~min}$ at temperatures indicated.

- - ALDH, - $-\mathrm{ADH}$. 


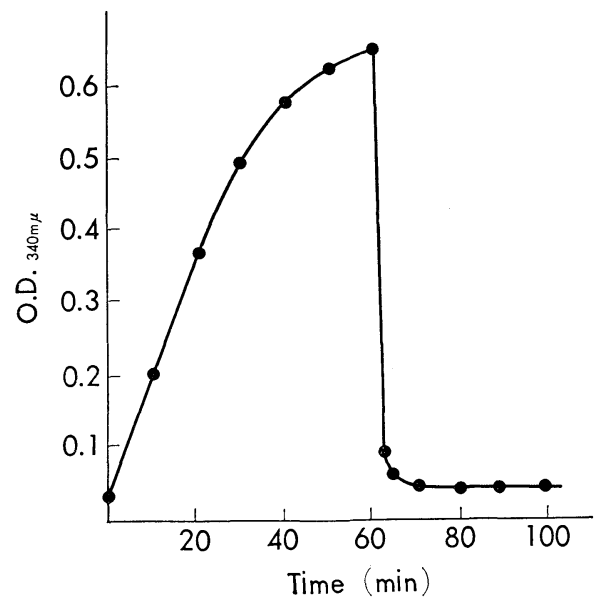

Fig. 6. Reversibility of the reaction catalyzed by $\mathrm{ADH}$.

Reaction mixture contained $300 \mu$ moles of ethanol, $1 \mu$ mole of $\mathrm{NAD}, 500 \mu$ moles of potassium phosphate buffer ( $\mathrm{pH} 8.0$ ) and enzyme in a final volume of $3.0 \mathrm{ml}$. The same mixture without enzyme was used as a blank. The reaction was started by the addition of enzyme, incubated for $60 \mathrm{~min}$ at $30^{\circ}$ and $300 \mu$ moles of acetaldehyde were added.

ADP or ATP showed respectively 48,42 or $38 \%$ inhibition of the reaction and it was concluded that these substances seemed to inhibit the reaction competitively for NAD from kinetic analysis. The $\mathrm{Ki}$ values of AMP, ADP and ATP were calculated as $7.5 \times 10^{-4} \mathrm{M}, 2.5 \times 10^{-3} \mathrm{M}$ and $8.6 \times 10^{-3} \mathrm{M}$, respectively.

\section{Properties of $A D H$}

Stoichiometry, reversibility and substrate specificity. After $60 \mathrm{~min}$ of the reaction with NAD and ethanol as substrates, the amount of $\mathrm{NADH}_{2}$ or acetaldehyde formed was estimated from the molecular absorbancy coefficient of $\mathrm{NADH}_{2}$ at $340 \mathrm{~m} \mu$ or color intensity at $560 \mathrm{~m} \mu$ developed by the method of BARKER and SUMMERSON (13), respectively, and it was confirmed that 98.8 $\mathrm{m} \mu$ moles of $\mathrm{NADH}_{2}$ were produced with formation of $97.8 \mathrm{~m} \mu$ moles of acetaldehyde. As shown in Fig. 6, $\mathrm{NADH}_{2}$ thus formed was completely oxidized by the addition of excess amount of acetaldehyde indicating that this dehydrogenase may catalyze reversible reactions. Substrate specificities of the enzyme in the forward and backward reactions are summarized in Table 3, and it was also found that NADP did not function as a coenzyme in this reaction. From these results, the reaction catalyzed by $\mathrm{ADH}$ of Leu. mesenteroides IFO 3426 may be shown by the following equation:

$$
\text { alcohol }+\mathrm{NAD} \rightleftharpoons \text { aldehyde }+\mathrm{NADH}_{2}
$$


Table 3. Substrate specificity of ADH.

\begin{tabular}{l|r}
\hline Substrate & Relative activity (\%) \\
\hline Forward reaction $^{a}$ & 0 \\
Methanol & 100 \\
Ethanol & 74 \\
Propanol & 0 \\
Isopropanol & 139 \\
Butanol & 0 \\
Isobutanol & 0 \\
Phenol & \\
Backward reaction & \\
Formaldehyde & 7 \\
Acetaldehyde & 100 \\
Propionaldehyde & 104 \\
Butyraldehyde & 125 \\
Isobutyraldehyde & 22 \\
Benzaldehyde & 0 \\
\hline
\end{tabular}

a Each substrate was added at a final concentration of $0.1 \mathrm{M}$.

$b$ Each substrate was added at a final concentration of $5 \mathrm{~mm}$.

Effect of $\mathrm{pH}$ and temperature. Optimum $\mathrm{pH}$ and temperature for the reaction were found to be 7.0 and $45^{\circ}$, respectively. The enzyme was inactivated by heat treatment at $50^{\circ}$ for $15 \mathrm{~min}$, as shown in Fig. 5 .

$\mathrm{Km}$ values. $\mathrm{Km}$ values for acetaldehyde, $\mathrm{NADH}_{2}$, ethanol and $\mathrm{NAD}$ were estimated as $6.9 \times 10^{-4} \mathrm{M}, 1.0 \times 10^{-5} \mathrm{M}, 1.4 \times 10^{-3} \mathrm{M}$ and $2.5 \times 10^{-5} \mathrm{M}$, respectively.

Effect of various compounds. The reaction was not inhibited in the presence of $10^{-3} \mathrm{M}$ of $\mathrm{K}^{+}, \mathrm{Na}^{+}, \mathrm{NH}_{4}^{+}, \mathrm{Li}^{+}, \mathrm{Mg}^{2+}$, EDTA, $\mathrm{Na}_{2} \mathrm{HAsO}_{4}$, iodoacetate, $\mathrm{NaN}_{3}$ or dipyridyl and $10^{-4} \mathrm{M}$ of $\mathrm{Ca}^{2+}, \mathrm{Zn}^{2+}, \mathrm{Fe}^{2+}$ or $\mathrm{Fe}^{3+}$. The reaction was, however, inhibited by $10^{-3} \mathrm{M}$-chloromercuribenzoate, $10^{-4} \mathrm{M}$ of $\mathrm{CuSO}_{4}$ or $\mathrm{AgSO}_{4}$ with 100, 35 or $16 \%$ inhibition, respectively. Although adenine, adenosine, ATP, guanine, guanosine, GMP and GDP did not inhibit the reaction at a concentration of $10^{-3} \mathrm{M}$, the same concentration of AMP and ADP showed 10 and $19 \%$ inhibition, respectively. It was also recognized that $10^{-3} \mathrm{M}$ of lactic acid, acetic acid, ethanol, acetyl phosphate and pyruvic acid showed no inhibitory effect on the reaction.

\section{Association of $A L D H$ and $A D H$}

As shown in Fig. 1, both ALDH and ADH were recovered in the void volume fractions of Sephadex G-200 column chromatography. This finding suggests a large molecular weight for these dehydrogenases. It was also mentioned earlier that activities of the enzymes could not be separated from 


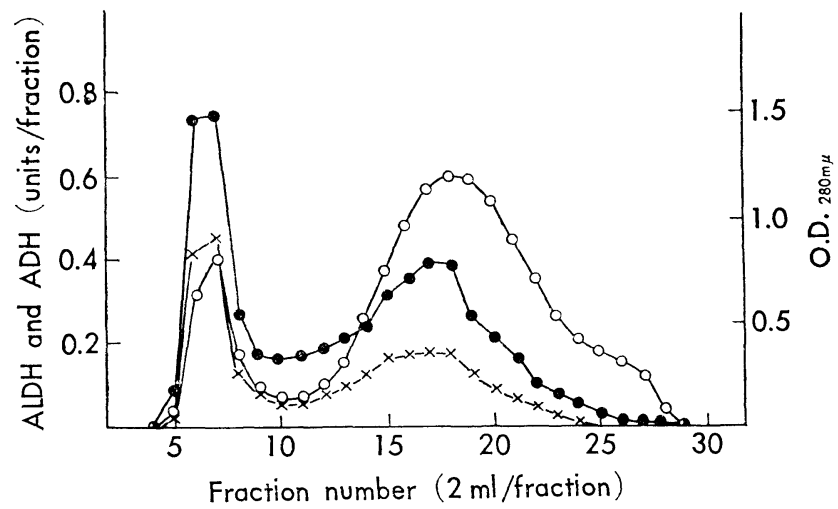

Fig. 7. Elution pattern of a Chromagel A-2 column.

$-\bullet-\mathrm{ALDH},-\times-\mathrm{ADH},-\mathrm{O}-\mathrm{OD}_{280 \mathrm{~m} \mu}$.

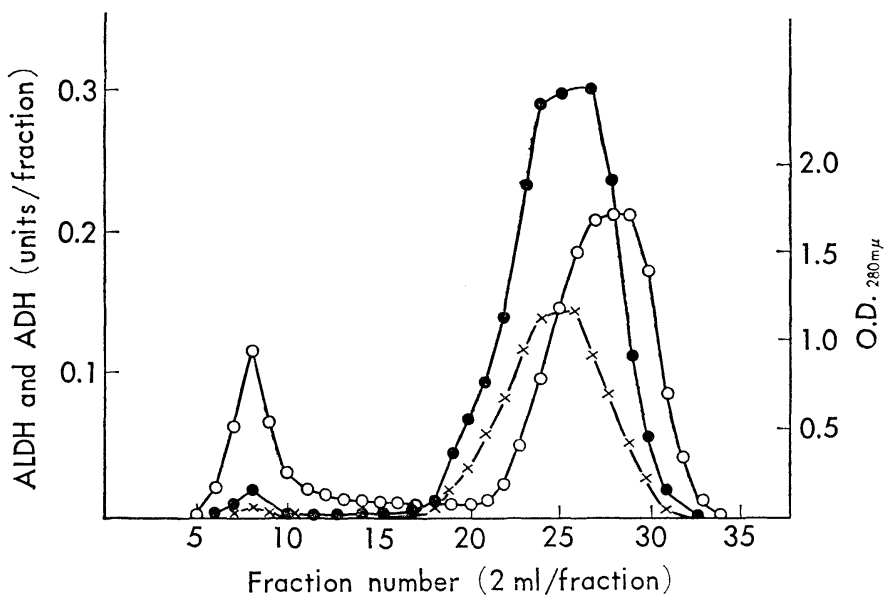

Fig. 8. Gel-filtration of RNase-treated enzyme preparation through Chromagel A-2 column.

Purified enzyme preparation (5.0 unit) in $2 \mathrm{ml}$ of phosphate buffer ( $\mathrm{pH} \mathrm{7.0)}$ was treated with $1 \mathrm{mg}$ of crystalline RNase $\mathrm{T}_{1}$ at $30^{\circ}$ for $60 \mathrm{~min}$, then $0.5 \mathrm{ml}$ of the reaction mixture was applied on a column of Chromagel A-2.

$$
-\mathrm{ALDH},-\times-\mathrm{ADH},-\mathrm{O}-\mathrm{OD}_{280 \mathrm{~m} \mu} \text {. }
$$

each other by various methods of enzyme fractionation. It seemed to be possible from the results described above that ALDH and ADH may exist as a multienzyme complex or enzymes associated with the same subcellular organelle in vivo. To assess this point, fractionation of these enzymes with a column $(1.6 \times 32 \mathrm{~cm})$ of Chromagel A-2 was tested. Chromagel (agarose) 
A-2 is usually used for separation of substances having 4-10 million molecular weight. Void volume (fraction Nos. 5 to 10 in Fig. 7) was estimated by using blue dextran as an indicator. The purified preparation of enzyme $(0.5 \mathrm{ml})$ was applied on the column of Chromagel A-2 which had been bufferized with $10^{-2}$ $\mathrm{M}$ of potassium phosphate buffer $(\mathrm{pH}$ 8.0) and eluted with the same buffer at a flow rate of $10 \mathrm{ml} / \mathrm{hr}$ at $5^{\circ}$. As shown in Fig. 7, the activities of the two dehydrogenases were detected in void volume fractions and fraction Nos. 11 to 25 with a constant ratio of activity in each fraction. It was also found that ultraviolet absorption spectrum of the eluate in each fraction was similar to that of RNA, suggesting the possibility of association of ALDH and ADH with subcellular particles containing RNA. As shown in Fig. 8, the molecular weight of purified enzyme was confirmed to shift to a lower weight by treatment of the enzyme by RNase $T_{1}$ at $30^{\circ}$ for $1 \mathrm{hr}$. When the enzyme preparation was treated without RNase $T_{1}$ under the same conditions, elution profile of the column chromatography was the same as shown in Fig. 7. From this fact, it seemed to be possible that artificial degradation of the associated enzyme did not occur under these treating conditions. The enzyme of lower molecular weight obtained by the RNase treatment and Chromagel A-2 column chromatography was found to be again emerged in void volume fraction of Sephadex G-200 column chromatography.

\section{DISCUSSION}

It has been reported that the reaction catalyzed by ALDH of Clostridium kluyveri requires the presence of $\mathrm{SH}$-compound and high ionic strength, and that the reaction is inhibited by sodium arsenate (14). Inhibition by sodium arsenate has also been found on ALDH of Pseudomonas fuorescens (15), yeast (16) and beef liver (17). These enzymic properties seem likely to be similar to those of ALDH of Leu. mesenteroides.

With respect to ALDH and ADH of Escherichia coli B, it has been reported that activities of the dehydrogenases cannot be separated from each other by various fractionation methods (18). As mentioned in this paper, $\mathrm{ALDH}$ and $\mathrm{ADH}$ of Leu. mesenteroides could not be separated from each other, and the ratio of $\mathrm{ALDH}$ to $\mathrm{ADH}$ activity seemed to remain relatively constant in the enzyme fractions prepared by various methods of protein purification. Moreover, it seems that both dehydrogenases of the organism may be associated with the same intracellular particles containing RNA. As one of possibilities, glucose 6-phosphate dehydrogenase and 6-phosphogluconate dehydrogenase may also be associated with an intracellular organelle to which both ALDH and $\mathrm{ADH}$ seem to bind, resulting in the efficient coupling of pyridine nucleotides which have been estimated to be reduced by the action of former two dehydrogenases and to be oxidized by latter dehydrogenases in anaerobic heterolactic fermentation. Although activities of $\mathrm{NADH}_{2}$ oxidase and $\mathrm{NADPH}_{2}$ oxidase were detected in the organism (9), it was previously reported that lactic 
acid formation by this organism was hardly affected by oxygen, while, under aerobic conditions, ethonol production decreased with a corresponding increase in acetate production indicating the existence of some mechanism of specific protection of lactic acid-forming system against the effect of oxygen $(8)$. It is very interesting that ALDH and ADH of the organism were detected as insoluble enzymes suggesting the possibility of different localization of lactic acid dehydrogenase and glyceraldehyde 3-phosphate dehydrogenase from ALDH, $\mathrm{ADH}, \mathrm{NADH}_{2}$ oxidase or $\mathrm{NADPH}_{2}$ oxidase.

Recently, it was reported that $\mathrm{ADH}$ of Leuconostoc mesenteroides, the strain number of which was unfortunately not mentioned, is composed of NADdependent and NADP-dependent enzymes which are tightly bound together, and molecular weight of the $\mathrm{ADH}$ was calculated to be 160,000 (7). With the strain of IFO 3426 used here, however, we found that partially purified NAD-linked ADH, which was found in the insoluble fraction of intracellular particles, does not contain NADP-linked $\mathrm{ADH}$. Although faint activities of NADP-linked ADH were detected in the crude cell-free extracts of this strain, details were not determined in the present study. As previously reported, 6phosphogluconate dehydrogenase and 2-oxogluconate 6-phosphate decarboxylase were detected as a bound enzyme in some strains, or free enzymes in other strains of heterolactic bacteria, and these facts indicated that there is a strainspecific localization of these enzymes in these bacteria (19-21). Further studies on the intracellular localization of ALDH and ADH in various strains of heterolactic bacteria may be very interesting with respect to physiological meaning of the relationship between the localization and function of these enzymes.

\section{REFERENCES}

1) J. Hurwitz, Biochim. Biophys. Acta, 28, 599 (1958).

2) R.W. Eltz and P.J. VAnDeMark, J. Bacteriol., 79, 763, (1960).

3) S. Yashima, K. Kawai, T. Kazahaya, Y. Okami and Y. Sasaki, J. Gen. Appl. Microbiol., 17, 173 (1971).

4) T. Nojiri, F. Tanaka and I. Nakayama, J. Biochem. (Tokyo), 69, 789 (1971).

5) R.D. DeMoss, R.C. BArd and I.C. Gunsalus, J. Bacteriol., 62, 499 (1951).

6) R.D. DeMoss, J. Bacteriol., 68, 252 (1954).

7) H. Hatanaka, O. Adachi, T. Chiyonobu and M. Ameyama, Agr. Biol. Chem. (Tokyo), 35, 1304 (1971).

8) S. Yashima, K. Kawai, Y. Okami and Y. Sasaki, J. Gen. Appl. Microbiol., 16, $543(1970)$.

9) K. Kawai, S. Yashima, Y. Okami and Y. Sasaki, J. Gen. Appl. Microbiol., 17, 51 (1971).

10) D. Dennis and N.O. Kaplan, J. Biol. Chem., 235, 810 (1960).

11) I.A. Rose, M. Grunberg-Manago, S.R. Korey and S. OchoA, J. Biol. Chem., 211, 737 (1954).

12) D.H. Lowry, N.J. Rosebrough, A.L. Farr and R.J. Randall, J. Biol. Chem., 193, 265 (1961). 
13) S.B. Barker and W.H. Summerson, J. Biol. Chem., 138, 535 (1941).

14) R.M. Burton and E.R. Stadtman, J. Biol. Chem., 202, 873, (1953).

15) W.B. JACOBY, J. Biol. Chem., 232, 75 (1958).

16) R.A. Peters, H.M. Sinclaire and R.H.S. Thompson, Biochem. J., 40, 516 (1946).

17) E. RACKer, J. Biol. Chem., 177, 883 (1949).

18) E.B. Rudolph, D.L. Purch and H.J. Fromm, J. Biol. Chem., 243, 5539 (1968).

19) S. Yashima and K. Kitahara, J. Gen. Appl. Microbiol., 14, 359 (1968).

20) S. Yashima and K. Kitahara, J. Gen. Appl. Microbiol., 15, 169 (1969).

21) S. Yashima and K. Kitahara, J. Gen. Appl. Microbiol., 15, 289 (1969). 